\title{
Problems \& Remedies of Non-Governmental Organizations (NGOS) in Jammu and Kashmir
}

\author{
Mashkoor Ahmad Lone ${ }^{1 *}$, Arsheed Ahmad Ganie ${ }^{2}$
}

\section{ABSTRACT}

The state of Jammu and Kashmir has misplaced its identity. The 1947 partition of the country has impressed long-lasting bitterness in the minds of people and draws a separating line (LOC) along the borders. It is definitely a hectic task to set up peace in the disturbed regions of the Jammu and Kashmir, but in no way outside the limits of opportunity. The civil societies and NGOs, being neutral in character, can play a peaceful role in maintaining peace and establishing of assurance among the people of the valley. NGOs are non-profit making agencies that are constituted with a dream by a group of same minded people, dedicated for the uplift of the poor, marginalized, unprivileged, underprivileged, impoverished, and downtrodden and the needy and they are closer and accessible to the target groups. Flexibility in administration, faster in decision making, timely in action and facilitating the people towards self-sufficiency ensuring their fullest participation in the whole process of development. The achievements and victory of NGOs in various fields and the brilliant work done by them in specific areas are no doubt an incredible task that has helped to meet the changing basic needs of the social system. Still, in spite of its achievements in various fields, NGOs are facing different types of problems which differ from organization to organization, region to region and from place to place. In this position, the present paper attempts to discuss some of the general problems faced by the NGOs and to provide some remedies to overcome these problems.

Keywords: Jammu and Kashmir, Non-Government Organization, civil societies, Programmes, Government and Problems.

The fifteenth of August 1947, not only changed the destiny of Indian people but also wrote a script of India's independence. The violence in Jammu and Kashmir grew extreme after the partition of the country in 1947 and with the evolution of militancy and cross border insurgency in 1989. The evilest face of this violence was seen in Jammu and Kashmir during last two and a

\footnotetext{
${ }^{1} \mathrm{Ph}$ D Research Scholar Annamalai University, Cuddalore, Tamil Nadu, India

${ }^{2} \mathrm{Ph}$ D Research Scholar Annamalai University, Cuddalore, Tamil Nadu, India

*Responding Author

(C) 2016 M Lone; licensee IJIP. This is an Open Access Research distributed under the terms of the Creative Commons Attribution License (http://creativecommons.org/licenses/by/2.0), which permits unrestricted use, distribution, and reproduction in any Medium, provided the original work is properly cited.
} 


\section{Problems \& Remedies of Non-Governmental Organizations (NGOS) in Jammu and Kashmir}

half decades. While the violence in the valley was on the go, an appearance for building peace and confidence among the people was felt, to defeat the situation and to control the violence in a peaceful manner. Among all the Agencies, Institutions and Organisations, the role of NonGovernmental Organisations (NGOs) was extensively different because of their sensitive and soothing approaches towards the process of peace building and development. The NGOs, being unique from that of government and other organisations, have improved the peace process in Jammu and Kashmir and worked continuously for the betterment of people affected by the violence. The Peace and prosperous building and non- governmental organisations (NGOs) are closely related to each other. The non-governmental organisations (NGOs) play a very important and predominant role in preventing the start or resumption of violence or conflict not only in Jammu and Kashmir but in almost every part of the world. The main aim of Peace building is violence prevention and reduction of tension in the valley. Before taking into relation the Peace building efforts in Jammu and Kashmir, one should appear into the matter attentively and point out the reasons for violence mainly in the state of Jammu and Kashmir. Previously to the India's independence in 1947, the generous state of Jammu and Kashmir was under the rule of Maharaja Dynasty. The emergence of building and maintaining freedom from strife in the violence area of Jammu and Kashmir was felt with the disturbance of militancy and cross border insurgency in 1989. The politically and socially recognised NGO's have the possible to force the government to meet the necessities of people in terms of maintaining peace and security in Jammu and Kashmir. two kinds of approaches for the prevention of violence; firstly the most important approach is the negotiated settlement or Peace building approach, to which most of the people on a global level would show acceptance. Secondly the Militaristic approach which cannot resolve the disputes alone, even though being capable of implementing calm the military employs use dissimilar techniques that may sometimes prove serious in a certain situation. So the work assigned to the NGOs and Civil Societies were best. The NGO's having no political significance, associate itself to the conflict prevention and Peace building processes in the psychologically disturbed areas of the state. Some peace NGO's presently active in Jammu and Kashmir, have pointed out certain important but unfavourable causes of violence like protests against Indian Government, father type rule, post-world war consequences and the alienation of trust, unfriendliness and sharpness from Indian federation. While some of the researchers find that terrorism and the military killing in the Kashmir valley have worsened the condition of the valley, ever since 1989 thereby hardening the labour of socially and politically recognised NGO's. Khan and Ayoub in their study provide a statistical data that the huge number of people in the state of Jammu and Kashmir has been affected by violence and economic downfall since 1989. Further Peace building and conflict prevention, the civil societies and NGO does have important role to play in the growth and progress of the state because of the neutral character and a sympathetic approach towards the affected persons. sensibly speaking, In order to bring about the Peace building efforts in a particular region, the NGO's have to carry on the Anthropological and geographical conditions of that region into consideration and join hands with local NGO's, institutions and communities to afford financial assistance to the needy and deserving people. 
For the establishment of peace in the disturbing region, the civil societies and NGO's have to be thrilling and honest and at the same time local communities should accompany NGO's to generate peace of reality. Though, people don't have great faith in the government and its institutions because of the personal interest of political leaders. The NGO's can act as the best intermediaries in loosening the tension among the states and countries. Why civil societies and NGO's were playing a vital role to maintain peace and help to restore normalcy in Kashmir? The answer lies in the background of violence between India and Pakistan in 1947. The destiny of people of Kashmir was to be decided by means of the plebiscite and some prerequisites were laid by the then leader Pt. Jawaharlal Nehru but India and Pakistan; both claimed the territory to be its own advantage which resulted in the erupting of violent violence, mass demonstration, and a feeling of a right to autonomy in the minds of people of Jammu and Kashmir. Further intensified form of this violence was seen in 1989 with the uprising of militancy and cross-border terrorism. Still the prospect further intensified in 2010, unrest in Kashmir. The dispute has now grown so intense that negotiations, Mediations and reducing tensions seem to have a lesser applicability. A creditable role has been played by various NGO's to rehabilitate the victims of 1989 insurgencies. This proved to be the main explanation for the requirement of NGO's to direct the state of Jammu and Kashmir towards the dawn of peace and an atmosphere free of violence and conflicts. The NGO's highlighted the problems of people in violence-ridden areas and forced mutually the counterparts (India and Pakistan) to take measures to settle the dispute of Kashmir harmoniously. It is because of NGO's that a bulk of people about the world came to know the problem of Kashmir. The civil societies and NGO's have not only prevented the human rights violation but also improved the socio-economic conditions of masses in the state of Jammu and Kashmir. The Chari and Chandra in their study reveal the different pathways to settle the dispute in Kashmir. Amongst the role played by various agencies, religion apart can play a very crucial role in the prevention of conflict because religion is of great essence and importance in a way that it decreases the bitterness between the countries. Almost whole of Asia is engaged in the violence and the concept of war and violence is at its peak, so the nation's peace and collective security gets compromised thereby forcing the international brotherhood to take quick steps to look into the issue. While pointing out the negative aspects of peace the Newman and Richmond in his own book "Challenges to Peace building: Managing Spoilers during Conflict Resolution” perceives that peace can have unfavourable effects if it is long-lasting and the actors could be considered as the spoilers to the violence.

\section{REVIEW OF LITERATURE}

In Jammu and Kashmir, India and abroad, several studies have been made on voluntary organizations (NGOs) working in rural as well as urban areas. Much of the literature on voluntary organizations in Jammu and Kashmir settings has come from usual social work. Many of the Anthropologists, Sociologists and Political Scientists are busy in the study of the voluntary organizations. Unluckily, communication among the disciplines about their findings has been distant from adequate. Michael Banton's book (1957) on the Anthropological Aspects of 
Voluntary Associations found that "NGOs become important and common as societies advance in technology, complexity and scale”. And also reveals that the relative functions as a means of organizing people in order to attain new ends, such as the increasing of capital, the guideline of prices and the provision of extra labour (Stefanovic et al., 2010). David sills, a sociologist, suggests the latent functions as opposite to the manifest functions of voluntary associations and distinguishes between the functions of relations for individuals and those for society. David smith has also revealed the assistance of formal voluntary organizations for society, attempting to well his analysis into a Parson Ian framework. He also found that the organizations bring out a role in each to Talcott Parsons four structural - functional categories of analysis, therefore contributing to societal adaptation, goal attainment, pattern maintenance and integration. Alliband Terry's on the study of voluntary agencies (1983) suggests that on the most extensively known successful experiments by voluntary orginisations such as Martandam and Sriniketan. The author understands comments specify some of the major drawbacks and advantages of voluntary agencies in the national rural development efforts of the third world nations. K.A. Suresh's (1990) study explains with the levels of the role of beneficiaries in the developmental programmes of select NGOs in Kerala. The author set up that NGOs are not functioning as participatory organizations to the extent desired. The rates of participation of beneficiaries and institutional activities for contribution are found to be very short. The beneficiaries are also found to be not devoted in getting represented in decision- making bodies and planning process. Vanitha Vishwanath's (1993) study explains the role of two NGOs i.e. Integrated Development Service and Gram Vikas in promoting women development. The author found that Gram Vikas is working more efficiently than Integrated Development Service. because those Gram Vikas programmes are intended in such a way that they give up fast results and are sensitive to the quick needs of the people. Vijay Mahajan (1994) made an effort to observe the role of NGOs and training institutions in DWCRA programme. His study revealed that there is a need for the NGOs and training institutions to make DWCRA programme new valuable. Roger C.Riddel and Mark Robinson (1995) in their review of sixteen projects on rural poverty improvement carried out by NGOs in India, Bangladesh, Uganda and Zimbabwe provided a detailed appraisal of the contribution of NGOs to improve rural poverty. They found that NGO projects were successful and effective in improving the social status of the poor; however, not all the projects were victorious in reaching the poor. M. Ramesh Singh (2004) in his study found that an effort to provide a better understanding of NGOs working in Manipur and their problems by taking up a micro level. He also conducted a study during 2000-2001 in two tribal villages in Manipur by name Khangshin and Minou and found that NGOs are playing an active role in development activities in the fields of education, health and sanitation, women and children to improve the quality of life.

\section{PROBLEMS OF NGOs}

Rural Reconstruction Society (RRS), Social Activities For Rural Development Society (SARDS), Community Action For Literacy and Livelihood (CALL), ASSIST, Rural Aid Service 
Organisation (RASO), Society for National Integration through Rural Development (SNIRD), Rural Development Society (RDS), Rural and Urban Development Society etc., are the some of the NGOs in Jammu and Kashmir are facing the following major problems.

\section{Lack of Funds}

Most of the NGOs Jammu and Kashmir are suffering from a dearth of funds. The government does not give cent percent grants in aid or make delay in sanctions of grants for various programmes. NGOs have to make matching contributions which NGOs are sometimes unable to supervise and are, therefore, unable to benefit themselves of the grants. Now a day's charity or trusts are not so strong in the people as it was in the ancient society. This was another region for the decay of funds for NGOs.

\section{Lack of Dedicated Leadership}

In NGOs Leadership qualities of the leaders confirm the quality and condition of the services rendered by any organization. Particularly dedicated leadership, 'Leadership for the sake of Leadership' is generally a chief governing factor in this regard. In the post independence period, unfortunately, the NGOs faced the crisis of leadership as the leaders who lead voluntary action and worked for it with the spirit of affection and dedication choose to go into politics to find a place in legislatures and parliament thus creating a blankness for dedication leadership in NGOs. With some expectations the leadership is determined in the hands of elderly people. The style of functioning of these elderly people exhibits dictatorship and frustrates younger people who are embodiments of new ideas, initiatives and innovation which are not allowed to be articulated and practiced (Mehta et al., 2010).

\section{Insufficient Trained Personnel}

It is supposed that the personnel working in NGOs may be of personnel working in such organizations are a sense of devotion and assurance and interest in the social services. NGOs earlier were supposed to be served by unpaid social workers imbued with the courage of service and did not need any special education or training. But the present trends that are having a professional education are not paying attention to work with NGOs. Their vision has been altered and is interested to work in urban areas only. For that reason, it is very hard to get trained persons who are either trained or willing to work in the rural society where the majority of NGOs work. Furthermore, these professionally trained persons have a high opportunity in terms of salaries, status, opportunities for their growth in the career of their choice. Moreover, due to lack of funds NGOs cannot able to spend some more funds for giving training to the personnel employed in the organization. A small number of NGOs is in fear of personnel who may transfer to another big NGO after taking training from it.

\section{Misuse of Funds}

In reality, that some dishonest members have made fortunes by floating NGOs for their personnel gains and managing grants from the government. It is a general experience that there have been serious charges of misuse and cheating of funds received as a grant- in-aid form the government, civil society, and foreign donors and raised throughout their own resources by the 
most of the NGOs. These NGOs may reveal its image to other NGOs who are working with dedication and loyalty.

\section{Monopolization of leadership}

It has been observed that at the top level there is a growing trend in the direction of monopolization and interlocking of leadership in various organisations, like in secretary, treasurer, a member of the executive and so on. This interlocking of leadership can be beneficial in formulating, coordinated programmes, policies, and activities, facilitating replace of technical known, and experience and mobilizing people for a common goal. But the greatest drawback of such leadership is that fresh blood is not allowed to flow into the organization and leadership.

\section{Lack of Public Participation}

Some of the factors responsible for such a state of affairs are general backwardness of the people, absence of sufficient number of devoted persons, political interference, over emphasis on targets and time bound programmes, and vested interests, easy availability of funds without proper planning and estimation of felt needs and safeguards for the community, distrust of agencies and workers who do not have a base in the community and are unable to win its support and lack of decentralization which could give a feeling of being partners in development rather than development being thrust from above.

\section{Centralization in Urban Areas}

NGOs are less developed in rural areas as compared to urban areas. The backwardness and ignorance of the rural people and lack of interest among social workers to them in the absence of availability of minimum comforts are the two most important reasons for the backwardness of the NGOs in rural areas.

\section{Lack of Coordination}

The lack of coordination between NGOs existing at national level state and local has laid to the common problems such as overlapping, non- coordination, duplication, etc, the absence of such an ordinary forum also incapacitates NGOs to offer united stand against the government when it humiliates them by irrelevant considerations at the behest of politicians and self-centred government officers. Furthermore, the state associations also do not facilitate the exchange of information, data collection, research, training and publication and also does not create favourable conditions where common difficulties can be placed before the government.

\section{Lack of Volunteerism}

NGO basic characteristic is volunteerism. In early days, youth are making their career in volunteerism but that enthusiasm seems to have dull these days. The scope of volunteerism is declining day by day and turning it into professionalization. Still the young graduates from social work are interested in making their career in professionalism. This leads to insufficiency of efficient volunteers in NGOs.

\section{Modernization}

Because of modernization, in management techniques introduction and professionalization, the traditional NGOs need certain least, infrastructure and administrative expenses. Sadly, grants-in- 
aid rules do not permit for such administrative expenditure excluding contingencies. This leads to the vanishing of traditional NGOs in the country which use to guide by great leaders.

\section{Target orientated and time-bound Programmes}

It has been observed that the supporter or administration that sanctions grants will put objective and time-bound programmes in front of NGO. Those NGOs will take the period but the qualities of service there is donation. This leads to declining in quality of service and is below expected standards.

\section{Area of Interest}

From time to time, NGO will desire the donor region of interest in welfare activities going beyond his own interest or working in more than one programme. This also leads to decline in quality of service in particular programme.

\section{REMEDIES}

The government of India has to loosen the rules and regulations of grants- in-aid and to sanction more grants to NGOs. At the same time, the government should select commissions of enquiry or committees to cross check the misuse of funds by NGOs. The member of the committee has to organize and observe the activities of NGOs periodically. Young graduates as of universities, colleges and schools have to perform the public meetings, seminars, symposiums and so on., and use the local media to announce the importance of volunteerism, achievement stories of NGOs and give confidence people to participate in voluntarism. With the same time, schools, colleges and universities have to cooperate with each other with NGOs and conduct campus interviews for the young graduates who are paying attention in voluntarism. NSS and NCC should support students to participate in voluntarism from childhood. To build leadership qualities to the coming generation the government of India has to establish the success stories of great leaders and their approach to leadership qualities, voluntarism, dedication and obligation towards social work in the curriculum of social work departments and in the school syllabus. In the state there must be coordinating organizations like Coordination Council of Voluntary Association (CCVA, Association of Voluntary Association for Rural Development (AVARD),) etc., to resolve the problems of NGOs. These associations are to facilitate the exchange of information in between the government and the NGOs. In $\mathrm{j}$ and $\mathrm{k} 68 \%$ of populations belong to rural areas. Therefore, NGOs need to operate in rural areas on a greater scale to enrol the cooperation of village people in making their life better. At the similar time, NGOs have to give confidence the educated young graduates of rural areas to take part in voluntarism. The government has also given some special support and provisions for NGOs who are functioning in rural areas in attaining eligibility conditions for grants. The government has to recognize those NGOs, by giving rewards or awards with additional grants. This would prompt the other NGOs to work efficiently. Monopolization of leadership should be removed. NGOs should recruit young and efficient people as leaders and retire the persons who are nominated members for very long tenures in any group or agency The NGOs should use of latest technologies like the internet, 


\section{Problems \& Remedies of Non-Governmental Organizations (NGOS) in Jammu and Kashmir}

websites, Browsing etc., for raising of their funds, to have mutual associations, to promote, announce, advertise their products and for the selection of efficient personals. The administration or supporter while sanctioning the grants for the particular programme has to careful the interest of that particular NGO.

\section{CONCLUSION}

NGOs are the ones who really propose to care and protect the uncared sections and the people at the bottom of the social stratum. Ours is developing state which requires these types of committed, devoted, enthusiastic and dedicated organizations for the development of the state. So, the government, administrators, rulers, the leaders, the donors, the politicians and the people should support these organizations and help them to solve their problems at the grass-root level than only their services are definitely and undoubtedly creditable in the upliftment of the rural poor.

\section{Acknowledgments}

The author appreciates all those who participated in the study and helped to facilitate the research process.

\section{Conflict of Interests}

The author declared no conflict of interests.

\section{REFERENCES}

Alliband, T. (1983). “Catalysts of Development-Voluntary Agencies in India”, Kumarian Press, Connecticut.

Almond, G.A. \& Sidney V. (1963). “The Civic Culture”, Princeton University Press, Princeton.

Banton, (1957). “West African City. A study of Tribal life in Freetown”, Oxford University, Press, London.

Bhatia, A. (2000). “Women’s Development and NGOs Jaipur and New Delhi”. Rawat Publications.

Bunker R. (1994). "Spirit of Voluntarism: The New Parasites”, Indian Express, p.8. Chowdhry,

D.P. (1987). "Critical appraisal of Voluntary Effect in Social Welfare and Development since Independence”, The Indian Journal of Public Administration, 333 Pp.492-500.

Gangrade, K.D. (1987). “Development of Voluntary Action”, Encyclopedia of Social Work, Ministry of Welfare, Government of India, New Delhi, p.227.

Ghosh, D.K. (2001). "NGOs Intervention in Poverty Alleviation”, Kurukshetra, March, pp.2-9.

Greene, S. (1994). "Non-Profit Groups' Expanding World, The Chronicle of Philosophy”, Vol.VI, No.18, p.27.

Gurulingaiah, M.(2002). "Role of NGO in Empowerment of Tribal Women in Karnataka, Kurukshetra”, . Inamdar Vol.51, No.2, Dec.Pp.30-33.

N. R. (1987). "Role of Voluntarism in Development", The Indian Journal of Public Administration, 333, Pp.420-432.

Kevin, B. (1994). “NGOs: A Resorting to Power”, Newsweek, Vol.CXXIV, No.5, August, p.14-15. 


\section{Problems \& Remedies of Non-Governmental Organizations (NGOS) in Jammu and Kashmir}

Kris, M.Y. Law, (2009). "Sustainable development in Non-Governmental Organizations: Factors affecting the Management Decisions - A study in Hong Kong”, International Journal of Sustainable Strategic Management,- Vol. 1, No.2, Taiwan, Pp. 204 - 219.

Kuponiyi, F.A. \& Ladele, A.A. (2007). “Involvement of Non-Government Organisations(NGOs) in Food Production and Welfare of Beneficiaries: The efforts of Fadu and Dadp in South Western Nigeria”, Journal of Human Ecology, Vol. 22, Dec., Pp.277-280.

Lawani, B.T. (1999). "NGOs in Development ( a case study of Solapur District)", Rawat Publications, for Policy Studies, The Johns Hopkins University, Baltimore (mimeo), p.3.

Mehta, D., Sharma, J. K., Mehta, N. K., and Jain A. (2010). “An empirical study on young executives' response towards pop-up and banner advertisements”, Serbian Journal of Management, Vol. 5, No. 1., pp 1-188.

Mohanan, S. (2000). “Micro-Credit and Empowerment of Women-Role of NGOs”, Yojana, February, Pp.21-28.

Pradeep, K. (2005). "Rural Development - A collaboration of GOs and NGOs”, Kurukshetra, Vol.53, N0.10, Pp.35-41.

Radha, K. (1993). "Voluntary Agencies in a Critical Decade”, Gandhi Marg, Vol.XV, No.3, p.287.

Ramesh, S.M. (2004). "NGOs Activities in Tribal areas of Manipur”. A Case Study, Vanyajati, January, Pp.3-9. Riddel,

R.C. \& Robinson. M. (1995). "Non-Governmental Organizations and Rural Poverty Alleviation”, Oxford. Clarendon Press.

Sachdev, D.R. (1992). “Social Welfare Administration In India”, Kitab Mahal 120 K. L. Latha / SJM 6 (1) (2011) 109 - 121Agency, Allahabad, p.205.

Shaline, M. (1988). "Role of Voluntary and Government Organisation in Tribal Welfare. A case study of Mandala District of Madhya Pradesh”. The Eastern Anthropologist, Vol.4- 1, Pp 49-64

Stefanovic, I., Damnjanovic, P. \& Jasko, O. (2010). "The analysis of the contemporary environment impact upon organizational operations”, Serbian Journal of Management 5 (1): 97 - 109.

Suresh, K.A. (1990). "Participation of Beneficiaries in the Development Programmes of NonGovernment Organization in Kerala”, Journal of Rural Development, 95, pp.911-915.

Umukoro, F.G., Owalobi, L.K. \& Sulaimon, A.A.-H. (2009). "Matching strategies to situations: Programmed and adaptive implementation approaches”, Serbian Journal of Management 4 (2): 259 - 272.

Vijay, M. (1994). “The Role of NGOs and Training Institution in DWCRA, NIRD, Hyderabad”. Journal of Rural Development , pp.9-909.

Vanitha, V. (1993). "NGOs and Women Development in Rural South India. A Comparative Analysis”, Vistaar Publications, New Delhi.

How to cite this article: M Lone (2016), Problems \& Remedies of Non-Governmental Organizations (NGOS) in Jammu and Kashmir, International Journal of Indian Psychology, Volume 3, Issue 4, No. 75, ISSN:2348-5396 (e), ISSN:2349-3429 (p), DIP:18.01.045/20160304, ISBN:978-1-365-50727-4

(c) The International Journal of Indian Psychology, ISSN 2348-5396 (e)| ISSN: 2349-3429 (p) | 58 